\title{
Consumption of the neonicotinoid thiamethoxam during the larval stage affects the survival and development of the stingless bee, Scaptotrigona aff. depilis
}

\author{
Annelise de Souza Rosa ${ }^{1}$, Juliana Stephanie Galaschi Teixeira ${ }^{1}$, Ayrton Vollet-Neto ${ }^{1}$, \\ Elisa Pereira QueIroz ${ }^{1}$, Betina Blochtein ${ }^{2}$, Carmen Sílvia Soares PIREs ${ }^{3}$, \\ Vera Lucia IMPERATRIZ-FONSECA ${ }^{1}$

\begin{abstract}
${ }^{1}$ Department of Entomology, University of São Paulo, Av Bandeirantes 3900, 14040-901, Ribeirão Preto, São Paulo, Brazil
${ }^{2}$ Department of Biology, Pontifícia Universidade Católica do Rio Grande do Sul, Av Ipiranga 6681, 90619-900, Porto Alegre, Rio Grande do Sul, Brazil

${ }^{3}$ Department of Ecology and Biosafety, Embrapa, Av W3 Norte, 70849-970, Brasília, Distrito Federal, Brazil
\end{abstract}

Received 31 August 2015 - Revised 21 November 2015 - Accepted 16 December 2015

\begin{abstract}
In Brazil, where the use of neonicotinoids is allowed in bee-attracting flowering crops, we investigated whether thiamethoxam intake during the larval stage of the native bee species Scaptotrigona aff. depilis affects the survival and development by exposing larvae to contaminated food. Our results indicated that the larvae exposed to the dose at a field-realistic level and to the doses ranging around it had their survival rates significantly impaired. At the highest doses, we observed larvae and pupae with shorter and longer development times, respectively, and the formation of smaller and asymmetric specimens. Evidently, we need to consider that thiamethoxam reaches the pollen and nectar at residual levels, and that they are processed by nurse bees before destined for offspring. Nevertheless, our findings suggest a warning, since the individuals had their biological parameters affected by thiamethoxam, when exposed to doses at field-realistic levels.
\end{abstract}

larval food / in vitro rearing / adverse effects / developmental stage / insecticides

\section{INTRODUCTION}

The use of neonicotinoid insecticides has been implicated as one of the main causes of the decline of pollinator populations worldwide (Goulson 2013; Van der Sluijs et al. 2013). The use of these insecticides in bee-attracting flowering crops is growing worldwide (Köhler and Triebskorn 2013), and the fact that their neurotoxic activity may affect pollinators justifies the increasing number of studies that seek to fill these gaps in knowledge (Gill et al. 2012; Arena and Sgolastra 2014; Costa et al. 2014; Fairbrother et al. 2014;

Corresponding author: A. Rosa,

annesouzar@gmail.com

Manuscript editor: Monique Gauthier
Feltham et al. 2014). Neonicotinoids can be sprayed, applied to the soil or applied as a seed coating (Blacquiere et al. 2012). In the last two cases, the active ingredient can reach pollen and nectar as residue (Rortais et al. 2005; Blacquiere et al. 2012) due to its systemic properties.

The stingless bees, which are important pollinators of the tropical regions for both wild and cultivated plants (Wilms et al. 1996; Del Sarto et al. 2005; dos Santos et al. 2008; Nunes-Silva et al. 2013), feed on pollen and nectar that are stored in the colony, with few exceptions (Nogueira-Neto 1997). The larval nutrition of this group of bees consists of the massive deposition of food from the nurse bees; the food is composed of honey, glandular secretions and pollen (Hartfelder and Engels 1989). Therefore, all of the food that will be consumed by the larva is 
deposited in the brood cell, which is operculated soon after the eggs are laid by the queen (Sakagami 1982). After returning from the field, the forager workers bring floral resources to the colony, which will be processed by nurse bees (Nogueira-Neto 1997) and offered to the offspring as larval food. Thus, if any residues contaminate the floral resources, the larvae in the colony will come into contact with the residue by eating the contaminated food (Villa et al. 2000).

Most studies on the effects of pesticides on bees have evaluated the adult stage (Moraes et al. 2000), mainly using the species Apis mellifera as a study model (Cresswell 2011; Costa et al. 2014; Fairbrother et al. 2014). Studies on the exposure of bees during the larval stage through in vitro rearing tests also focus on this species (Aupinel et al. 2007; Hendriksma et al. 2011; Wilkins et al. 2013; Tavares et al. 2015). However, Kremen et al. (2002), Del Sarto et al. (2005) and Tomé et al. (2015) highlighted the importance of native pollinators in the context of insecticide use in agriculture. Despite their importance as native pollinators in Brazil, the first and only study to date that addressed the exposure of stingless bees during the larval stage to insecticides was published by Tomé et al. (2012). In their study, the authors observed several adverse effects of the neonicotinoid imidacloprid on Melipona quadrifasciata anthidioides .

In Brazil, the native stingless bee species Scaptotrigona aff. depilis Moure, 1942 visits a wide range of floral resources, such as citrus, eucalyptus (Faria et al. 2012) and cotton flowers (Pires et al. 2014), crops on which the use of neonicotinoids is common (Ministério da Agricultura, Pecuária e Abastecimento 2015). In addition, the wide distribution of this native stingless bee species in the Neotropical region (Moure et al. 2013) makes it an important species for research. Therefore, we selected $S$. aff. depilis as a model to assess the potential risks that thiamethoxam, an insecticide of the neonicotinoid chemical group, offers to native bees by evaluating the sublethal effects of larval feeding in vitro. To determine the effects of thiamethoxam intake during the larval stage, we investigated whether the survival rate of $S$. aff. depilis specimens in each developmental stage decreases with increasing thiamethoxam doses and whether thiamethoxam intake affects the development time of immature individuals and the size and asymmetry of adults. Our findings indicate that the consumption of thiamethoxam during the larval stage causes delayed development of immature individuals and the formation of smaller and asymmetric $S$. aff. depilis specimens.

\section{MATERIAL AND METHODS}

\subsection{Study site and studied species}

This study was performed at the University of São Paulo, Ribeirão Preto campus, and the bee species chosen as the study model was $S$. aff. depilis .

\subsection{Insecticide and diet}

The active ingredient thiamethoxam (Pestanal $\AA$, analytical standard-Fluka) was obtained from Sigma Aldrich, UK. A stock solution of $0.125 \mathrm{ng}$ of thiamethoxam $/ \mu \mathrm{L}$ of distilled water was prepared and was added to larval food (using a vortex mixer). The doses of thiamethoxam provided to the larvae were based on the recommended concentrations for use on citrus crops in Brazil (translated to ng of active ingredient/larva): 0.0 (CS, control with solvent); 0.004 (T1 = one tenth of the maximum recommended concentration "MRC"); 0.044 (T2 = "MRC"); and 4.375 (T3 = 100 times more than the "MRC"). The control group was identified as NC (negative control, no solvent). Thiamethoxam is frequently applied on these crops, whose flowers are commonly visited by stingless bee S. aff. depilis (Faria et al. 2012).

\subsection{In vitro rearing of stingless bees}

The technique used for in vitro bioassays was adapted from the method developed by Menezes et al. (2013). For the experimental design, we considered and adapted the standard methods for toxicity testing in A. mellifera (Medrzycki et al. 2013).

Brood combs from different colonies of $S$. aff. depilis were used. One or two combs containing larvae of approximately $24 \mathrm{~h}$ of age were collected from each colony, and the larval food was recovered from these combs and subsequently homogenised for the experiments. We used the same material to measure the 
amount of food that each brood comb should contain with the aid of microcapillaries. Thus, each cell of an acrylic plate received $35 \mu \mathrm{L}$ of larval food, and the plates were then placed in a controlled-temperature incubator $\left(28\right.$ to $\left.29^{\circ} \mathrm{C}\right)$ for $48 \mathrm{~h}$. Next, the larvae were transferred from the natural honeycombs to acrylic plates, which were returned to the incubator. Four replicates with 50 specimens were evaluated for each treatment and the control group. Each replicate contained larvae from a single colony. For a humidity control, we used the treatment with the highest survival rate (97.9\%) reported by Menezes et al. (2013): $100 \%$ humidity for the first 6 days after transferring the larvae to the acrylic plates and $75 \%$ humidity for the additional development time.

\subsection{Development}

Biological parameters significant for larval development were evaluated through daily specimen monitoring. The parameters were as follows: (a) mortality rate from larval transfer to adult emergence; (b) development time of the specimens at each stage (larva, pre-pupa and pupa), considering the surviving individuals. Dead specimens were identified by the absence of spiracle movement and were removed from the plates.

\subsection{Morphometric analysis}

The adult workers that emerged were collected for morphometric analysis [NC $(n=73)$; CS $(n=83)$; T1 $(n=88)$; T2 $(n=77)$; T3 $(n=77)]$, while the males were discarded. The specimens were photographed using a stereoscopic microscope (Leica MZ16) connected to a digital camera (Leica DFC500) and Leica Application Suite (LAS 3.8.0 software), from Switzerland, for measuring the head width and the intertegular span.

Then, the anterior wings of the same specimens were removed and mounted on slides. The anterior wings were also photographed, and a .tps file was created from the image file in the software tpsUtil version 1.40 (Rohlf 2008). Then, 11 anatomical landmarks of the branching point of the wing veins were identified and established using tpsDig version 2.12 software (Rohlf 2008) to assess the wing asymmetry through parameters such as the centroid size (the square root of the sum of squared deviations of landmarks around their centroid or centre of mass) and wing shape (through wing venation patterns) (Klingenberg et al. 1998).

\subsection{Statistical analysis}

The mortality results were subjected to procedure Survival Analysis, in which survival curves were obtained through Kaplan-Meier estimators. The bees that survived until emergence were treated as censored data. The survival curves of each treatment were compared using the Log-rank test (with significance levels of 0.05). Analysis of variance (ANOVA) was used to compare the means of the development time, intertegular span and head width between treatments, after assessing the data normality, through the Kolmogorov-Smirnov-Lilliefors test. Next, Tukey's post hoc tests (with significance levels of 0.05 ) were used for analysis of the parameters with significant differences in ANOVA. The analyses were performed in SPSS 17.0 software.

Concerning wing morphometry, a standard ANOVA for fluctuating asymmetry was used in the analysis of the centroid size (Palmer and Strobeck 1986), and a corresponding Procrustes ANOVA was used for analysis of the wing venation patterns (Klingenberg et al. 1998). These analyses were performed in MorphoJ version 1.03 software (Klingenberg 2011).

\section{RESULTS}

\subsection{Development}

The curves obtained from Kaplan-Meier estimators showed that the survival of $S$. aff. depilis larvae exposed to thiamethoxam was significantly impaired (Log-rank: $X^{2}=74.6$; $P<0.001$ ) (Figure 1). The survival curves indicated that the group treated with the highest dose of thiamethoxam (T3) had a significant decrease in survival (43.7\%), comparing to the groups $\mathrm{NC}$ $(80.3 \%)\left(X^{2}=40.1 ; P<0.001\right), \operatorname{CS}(74.6 \%)$ $\left(X^{2}=28.8 ; P<0.001\right)$ and $\mathrm{T} 1(68.5 \%)\left(X^{2}=\right.$ $18.8 ; P<0.001)$. Only the T2 $(45.0 \%)$ was similar to the T3 $\left(X^{2}=0.05 ; P=0.82\right)$ and different from the other treatments. When comparing $\mathrm{T} 1$ and $\mathrm{T} 2$ to $\mathrm{NC}$, we can also observe a decrease in survival. No differences were found between the groups $\mathrm{NC}$ and $\mathrm{CS}$ $\left(X^{2}=1.2 ; P=0.26\right)$.

Regarding the development time of each stage (Figure 2) after exposure to different doses of thiamethoxam, there was a significant difference 


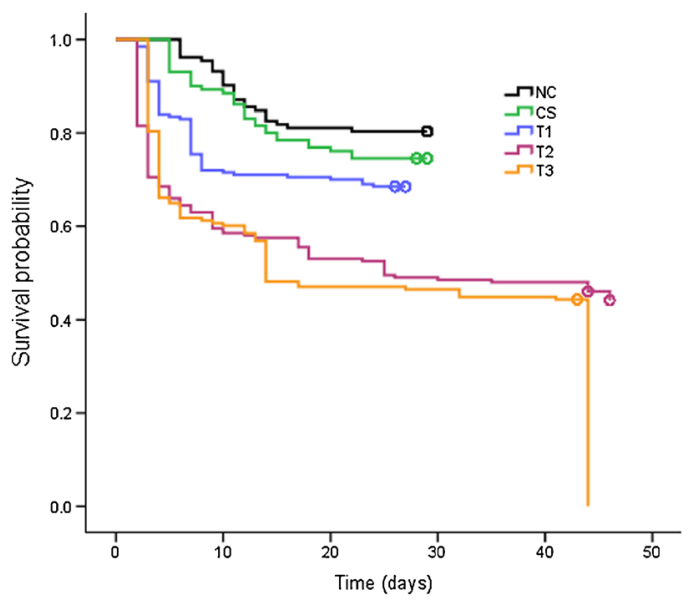

Figure 1. Survival probability of $S$. aff. depilis specimens until the last pupal stage in each treatment. NC (negative control), CS (control with solvent: $0.0 \mathrm{ng} /$ larva), T1 (0.007 ng/larva), T2 (0.044 ng/larva) and T3 (4.375 ng/larva). Survival curves are indicated by Kaplan-Meier estimators. Circles indicate the censored data (bees that survived until emergence).

between treatments in the larval stage, and larvae exposed to T2 and T3 had shorter development times (ANOVA, $\mathrm{F}=48.5, P<0.001$; Tukey's post hoc test significant at $P<0.05$ ). The duration of the pre-pupal stage was not different between groups (ANOVA, $F=1.30$,

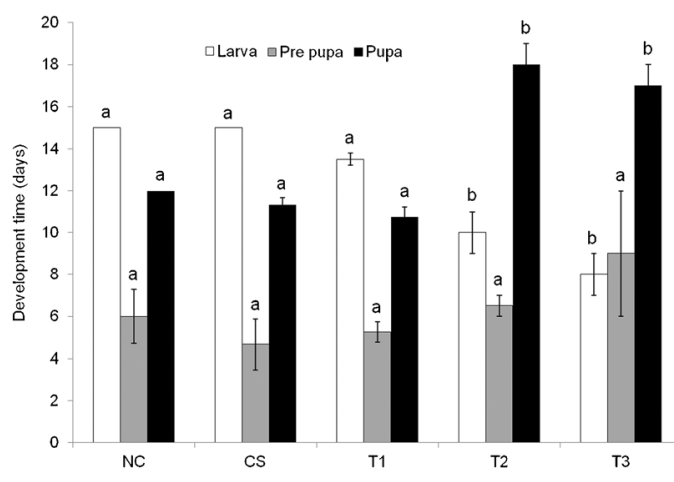

Figure 2. Development time of $S$. aff. depilis specimens in each developmental stage (represented by columns) in each treatment. NC (negative control), CS (control with solvent: $0.0 \mathrm{ng} / \mathrm{larva}), \mathrm{T} 1$ (0.007 ng/larva), T2 (0.044 ng/larva) and T3 (4.375 ng/larva). Different letters indicate statistical difference (Tukey's test, significant at 0.05 ). The comparison of means indicated by the letters was performed between the columns corresponding to the same developmental stage.
$P>0.5$ ), while in the pupal stage (ANOVA, $F=38.62, P<0.0000$ ), the specimens had significantly longer development times at the higher doses (T2 and T3).

\subsection{Morphometric analysis (head width, intertegular span and wing asymmetry)}

The head width (ANOVA, $F=1238.0$, $P<0.01$ ) and the intertegular span (ANOVA, $F=1766.4, P<0.01)$ of the workers were significantly affected by the presence of thiamethoxam. Individuals of the CS and T1 groups showed a tendency to increase the size of both measures (Figure 3): the head width was found to be mean $3.59 \mathrm{~mm} \pm 0.03 \mathrm{SE}$ for bees from $\mathrm{NC}$, while at the $\mathrm{CS}$ and $\mathrm{T} 1$ were means $3.74 \mathrm{~mm} \pm 0.02 \mathrm{SE}$ and $3.80 \mathrm{~mm} \pm 0.01 \mathrm{SE}$, respectively; the intertegular span was found to be mean $2.43 \mathrm{~mm} \pm 0.01 \mathrm{SE}$ for bees from $\mathrm{NC}$, while at the $\mathrm{CS}$ and $\mathrm{T} 1$ were means $2.55 \mathrm{~mm} \pm 0.01 \mathrm{SE}$ and $2.54 \mathrm{~mm} \pm 0.008 \mathrm{SE}$, respectively. However, specimens fed with the higher doses of thiamethoxam exhibited significantly lower values for both the head width (T2, $2.37 \mathrm{~mm} \pm 0.01 \mathrm{SE} ; \mathrm{T} 3,2.32 \mathrm{~mm} \pm 0.01 \mathrm{SE})$ and the intertegular span $(\mathrm{T} 2,1.68 \mathrm{~mm} \pm 0.01 \mathrm{SE} ; \mathrm{T} 3$, $1.53 \mathrm{~mm} \pm 0.01 \mathrm{SE}$ ) (Figure 3) compared to the specimens of the other groups. Figure $4 \mathrm{a}-\mathrm{e}$ illustrates the comparison of the body size among the groups.

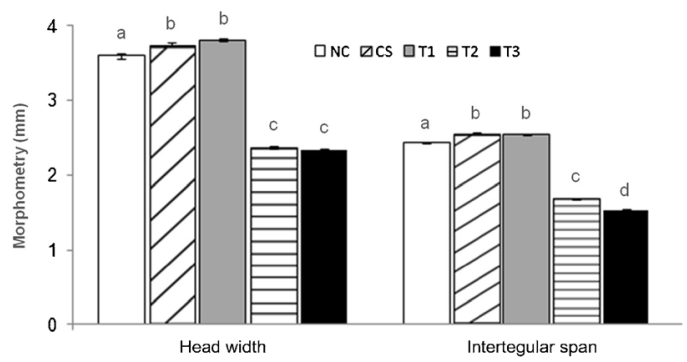

Figure 3. Morphometric measures (mean in $\mathrm{mm}$ ) of $S$. aff. depilis workers fed diets with and without the insecticide thiamethoxam. $a$, head width; $b$, intertegular span. Columns represent the treatments: $\mathrm{NC}$ (negative control), CS (control with solvent: $0.0 \mathrm{ng} /$ larva), T1 (0.007 ng/larva), T2 (0.044 ng/larva) and T3 (4.375 ng/larva). Bars indicate the mean standard error values. Different letters indicate significant differences $(P<0.05)$. 

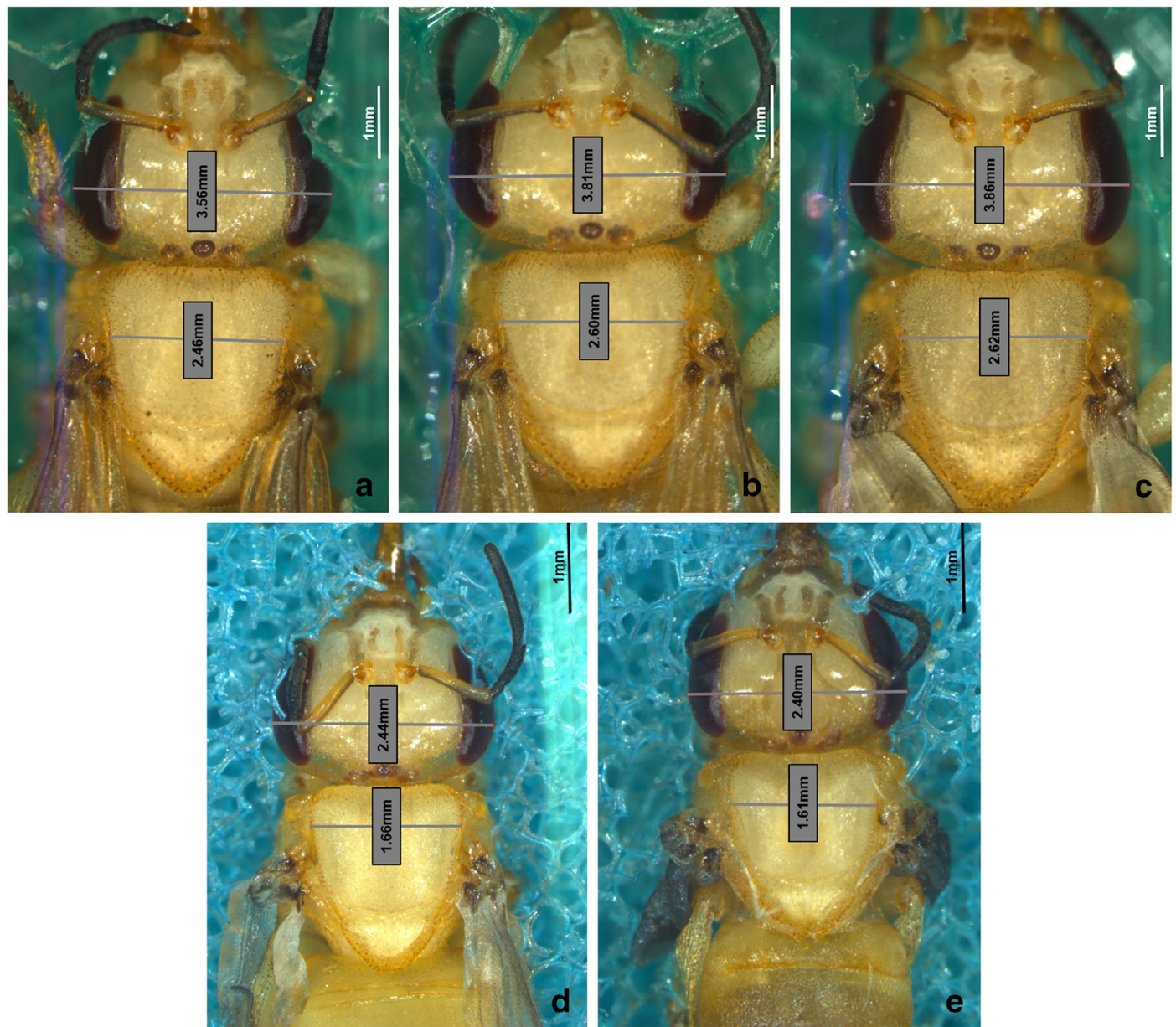

Figure 4. Head width and intertegular span of $S$. aff. depilis workers fed diets with and without the insecticide thiamethoxam. a NC (negative control); b CS (control with solvent, $0.0 \mathrm{ng} / \mathrm{larva}$ ); c T1 (0.007 ng/larva); d T2 ( $0.044 \mathrm{ng} / \mathrm{larva})$; and e T3 (4.375 ng/larva). Values within the squares indicate the means of the morphometric measures.

Regarding the wing morphometry, the centroid size was significantly different in all treatments according to the ANOVA results, but there was no difference between the left and right sides of the same specimen (Table I). Thus, for the centroid size, we did not detected asymmetry among workers. Regarding the wing venation pattern, which was analysed using Procrustes ANOVA, the $\mathrm{NC}$ and CS groups were statistically different only in terms of interindividual variation and not between the left and right sides of the same individual, i.e. the $\mathrm{NC}$ and $\mathrm{CS}$ specimens were not asymmetric. The specimens exposed to $0.004 \mathrm{ng}$ thiamethoxam/larva
(T1) were significantly different in both the variation between individuals and the variation between sides. Furthermore, in T1, the magnitude of the mean squares for both parameters evaluated was similar, indicating that both parameters are important for concluding that the specimens are asymmetric. In T2 and T3, both the variation between individuals and the variation between sides were significant, but the magnitude of the mean squares between sides was higher than between individuals. Because the difference between sides is primarily responsible for shape variation, the $\mathrm{T} 2$ and $\mathrm{T} 3$ specimens are also considered asymmetric. 


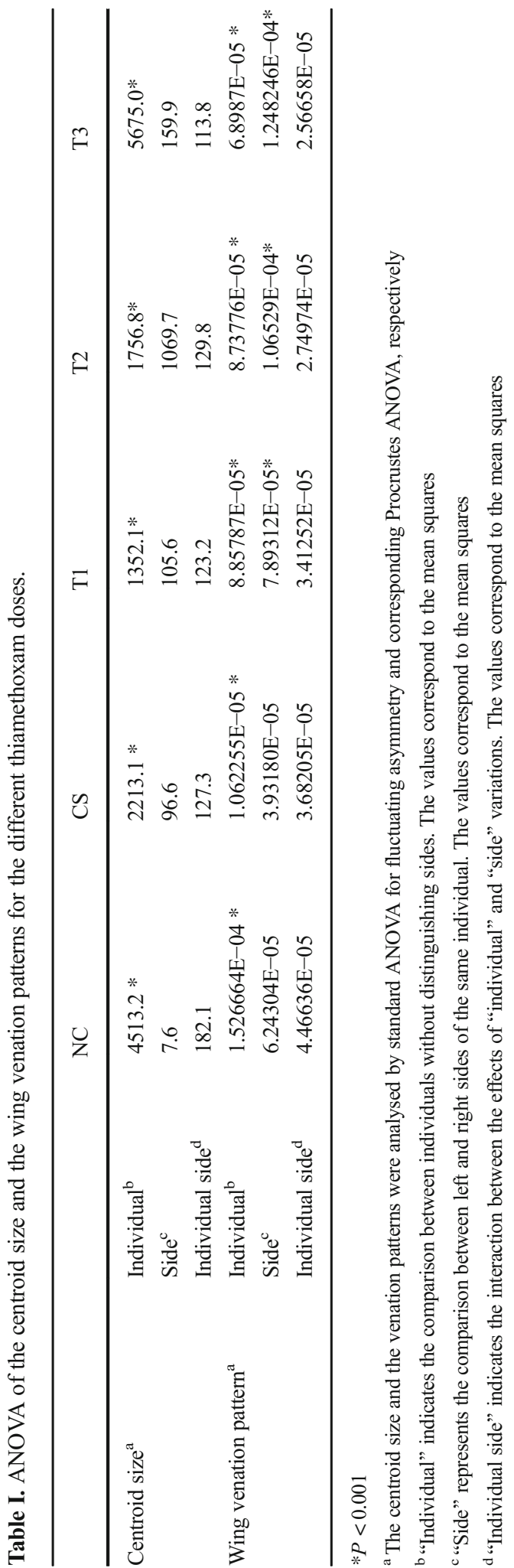

\section{DISCUSSION}

The currently concern regarding bee population losses and its link to the use of neonicotinoids has focused investigations on honey bees (Godfray et al. 2014). On the other hand, Tomé et al. (2015) and Barbosa et al. (2015) emphasise the importance of including native pollinators in risk assessments of pesticides, and highlight the stingless bees in the Neotropical region. In this context, recently, Rosa et al. (2015) detected the presence of neonicotinoids thiamethoxam and imidacloprid in forager bodies of $S$. aff. depilis that were returning to the colony after foraging, maintained at meliponary, at University of São Paulo, Brazil. In eusocial bees, as honey bees and stingless bees, the pollen and nectar collected in the field by forager workers are later processed by nurse bees, and are ultimately destined for offspring, composing the larval food (Hartfelder and Engels 1989; Blacquiere et al. 2012). Thus, if any residues contaminate the floral resources, the larvae in the colony will come into contact with the residue by eating the contaminated food (Villa et al. 2000; Blacquiere et al. 2012). The in vitro rearing technique used in the present study proved satisfactory for studies on the development of stingless bees exposed to insecticides during the larval stage. The mortality rate of the control group was the lowest between the treatments $(13.2 \%)$ and was similar to those observed in studies with A. mellifera (Fukuda and Sakagami 1968).

Our results indicated that the specimens exposed to the higher doses of thiamethoxam during the larval stage (0.044 and $4.375 \mathrm{ng} / \mathrm{larva})$ had significantly lower survival rates compared to the NC. It corroborates earlier findings about high toxicity of thiamethoxam on honey bee larvae (Tavares et al. 2015). Tomé et al. (2012) also reported adverse effects of neonicotinoid on stingless bees, showing significant reduction on survival rates of larvae of $M$. quadrifasciata anthidioides, when exposed to imidacloprid. At the highest doses (T2 and T3), our study revealed significant acceleration and delay in larval and pupal development times, respectively. In this context, Tavares et al. (2015) showed that sublethal doses of thiamethoxam for honey bees can cause atypical progression of larval development 
stages. In addition, Wu et al. (2011) reported delay in the development of A. mellifera workers exposed to pesticide residues, including neonicotinoids, and suggested that it could have negative consequences in the long term, e.g. affecting several activities, such as brood care, food processing and storage, queen care, hygienic behaviour and foraging efficiency.

Besides the consequences on the survival and development time, the presence of variations in important morphological landmarks, such as intertegular span and head width (Lima et al. 2011, 2013), and/or size and shape of wings due to the intake of residues during the larval stage, should be taken into consideration, as these changes can later affect the bees' activities within the colony (Wu et al. 2011). In this context, the workers exposed to the highest doses of thiamethoxam in our tests produced smaller specimens compared to the control group. Furthermore, the thiamethoxam intake, even at the lowest dose, caused wing shape asymmetry. Tavares et al. (2015) also found reduction in body size of individuals of $A$. mellifera exposed to high concentrations of thiamethoxam (20, 50 and $100 \mathrm{ng} / \mu \mathrm{L}$ of larval diet). In addition, Higginson and Barnard (2004) found that the increased wing asymmetry results in reduced flight efficiency of A. mellifera workers. Thus, we may infer that if smaller stingless bees with decreased intertegular span caused by thiamethoxam intake during the larval stage reach the foraging age, they would potentially show changes in their activities efficiency for the colonies. The morphometric parameters used in our study indicated sublethal effects of thiamethoxam in the short term. Therefore, we emphasise the importance of using morphometric parameters as indicators of adverse effects in studies that evaluate the exposure of bees to insecticides during the larval stage.

Decourtye and Devillers (2010) stated that several studies have assessed the effects of neonicotinoids on adult bees but warned that the adverse effects on the offspring may have more serious consequences for the colony health than the loss of older bees such as foragers. The delayed development coupled with worker malformation, found in our study, could potentially weaken the colony in the long term and promote susceptibility to diseases and consequent decreases in fitness.

From the results presented, we concluded that the larvae exposed to the dose at a field-realistic level (T2) and to the doses ranging around it (T1 and T3) had their survival rates significantly impaired. Other findings are regarding the adverse effects verified on the larval and pupal development time, the body size and wings asymmetry, observed just at the T2 and T3. Evidently, we need to consider that, as a systemic insecticide, thiamethoxam reaches the pollen and nectar at residual levels. Dively et al. (2015) have conducted experiments to track the movement and degradation of imidacloprid within whole colonies of honey bees to better understand the fate of imidacloprid doses used in the sublethal experiments. The authors found about 1/ 166 of the imidacloprid from a patty ending up in RJ and in larvae. For both honey bees and stingless bees, the food is processed by nurse bees and is ultimately destined for offspring. Thus, it is relevant to consider the degradation of active ingredients also in colonies of stingless bees.

In this context, a factor that could maybe influence the amount of residues that reaches the larvae is the difference in the type of larval feeding between honey bees and stingless bees. In honey bees, adult workers inspect the brood cells and progressively deposit food for the larvae. However, the proportion of pollen is small in relation to the proportion of nectar present in larval food (Haydac 1970). Haydac (1970) does not consider pollen to be an essential component of the larval diet in this species. On the other hand, larval nutrition in stingless bees consists of the en masse deposition of food by nurse bees (Roubik 1982; Hartfelder et al. 2006). Thus, all food to be consumed by a larva is deposited in the brood cell, and after the queen lays her eggs, the cells are operculated (Sakagami 1982). The highest consumption of pollen by stingless bees occurs during the larval stage (Zerbo et al. 2001). Another factor to be considered, for instance, is the ability of detoxification of the active ingredients by adult worker bees. In this context, Suchail et al. (2004) found that 6 and $24 \mathrm{~h}$, respectively, after ingestion of imidacloprid at 20 and $50 \mathrm{\mu g} \mathrm{kg}^{-1}$ bee, imidacloprid could no longer be detected in the 
adult honeybee. In addition, Rosa et al. (2015) found that forager workers of the stingless bee species $S$. aff. depilis contaminated with imidacloprid, after $24 \mathrm{~h}$ of confinement with non-contaminated diet, had peaks revealing imidacloprid was still present. However, for stingless bees there are still no studies on pesticide residues, and thus, it is difficult to accurately estimate the amount of residue that one larva of stingless bees consumes.

Anyway, our findings suggest a warning, since the larvae of $S$. aff. depilis had their biological parameters affected by the consumption of thiamethoxam, when exposed to a dose one tenth of the "MRC" for use on citrus, crop whose flowers are commonly visited by this stingless bee species. Additionally, another point is that thiamethoxam is also applied on other bee-attracting flowering crops in Brazil (other than citrus), and the recommended concentration for use in the field may vary among them. Regarding the use of pesticides on agroecosystems, Guedes et al. (2015) highlights that its use is guided by short-term efficacy; the indirect and subtler effects of pesticides on their target arthropod pest species have been neglected. The authors warn that potential long-term impacts should be considered.

In this context, our findings suggest that the thiamethoxam effects on $S$. aff. depilis specimens can be observed over the long term. Thus, we also reinforce the importance of considering other species of stingless bees for risk analyses of insecticide use. Our study contributed with important information for in vitro rearing tests that assess the exposure of stingless bees to insecticides during the larval stage.

\section{ACKNOWLEDGMENTS}

The authors thank the School of Philosophy, Science and Letters of Ribeirão Preto (Faculdade de Filosofia, Ciências e Letras de Ribeirão Preto-FFCLRP) of the USP for providing the facilities for conducting the experiments. Thanks are also due to Dr Tiago Maurício Francoy for helping with the fluctuating asymmetry analysis, and to Lucas Lima Fontana for helping with editing images. Finally, thanks to Conselho Nacional de Desenvolvimento Científico eTecnológico for financial support.
La consommation du néonicotinoïde thiaméthoxane durant le stade larvaire affecte la survie et le développement de l'abeille sans aiguillon, Scaptotrigona aff. depilis

alimentation de la larve / élevage in vitro / effets secondaires / insecticide / stade de développement / Meliponini

Die Aufnahme des Neonikotinoids Thiamethoxam mit der Nahrung in der Larvalphase beeinflusst die Überlebensrate und die Entwicklung der Stachellosen Biene Scaptotrigona aff. depilis

Larvenfutter / in vitro Aufzucht / negative Effekte / Entwicklungsstadium / Insektizide

\section{REFERENCES}

Arena, M., Sgolastra, F. (2014) A meta-analysis comparing the sensitivity of bees to pesticides. Ecotoxicology 23 (3), 324-334

Aupinel, P., Fortini, D., Michaud, B., Marolleau, F., Tasei, J.N., Odoux, J.F. (2007) Toxicity of dimethoate and fenoxycarb to honey bee brood (Apis mellifera), using a new in vitro standardized feeding method. Pest Manag. Sci. 63 (11), 1090-1094

Barbosa, W.F., Smagghe, G., Guedes, R.N.C. (2015) Pesticides and reduced-risk insecticides, native bees and pantropical stingless bees: pitfalls and perspectives. Pest Manag. Sci. 71 (8), 1049-1053

Blacquiere, T., Smagghe, G., Van Gestel, C.A., Mommaerts, V. (2012) Neonicotinoids in bees: a review on concentrations, side-effects and risk assessment. Ecotoxicology 21 (4), 973-992

Costa, E.M., Araujo, E.L., Maia, A.V., Silva, F.E., Bezerra, C.E., Silva, J.G. (2014) Toxicity of insecticides used in the Brazilian melon crop to the honey bee Apis mellifera under laboratory conditions. Apidologie 45 (1), $34-44$

Cresswell, J.E. (2011) A meta-analysis of experiments testing the effects of a neonicotinoid insecticide (imidacloprid) on honey bees. Ecotoxicology 20 (1), $149-157$

Decourtye, A., Devillers, J. (2010) Ecotoxicity of neonicotinoid insecticides to bees. In: Thany, S.H. (ed.) Insect nicotinic acetylcholine receptors, pp. 8589. Springer, New York

Del Sarto, M.C.L., Peruquetti, R.C., Campos, L.A.O. (2005) Evaluation of the neotropical stingless bee Melipona quadrifasciata (Hymenoptera: Apidae) as pollinator of greenhouse tomatoes. J. Econ. Entomol. . doi:10.1093/jee/98.2.260

Dively, G.P., Embrey, M.S., Kamel, A., Hawthorne, D.J., Pettis, J.S. (2015) Assessment of chronic sublethal 
effects of imidacloprid on honey bee colony health. PLoS One 10 (3), e0118748

dos Santos, S.A., Roselino, A.C., Bego, L.R. (2008) Pollination of cucumber, Cucumis sativus L. (Cucurbitales: Cucurbitaceae), by the stingless bees Scaptotrigona aff. depilis moure and Nannotrigona testaceicornis Lepeletier (Hymenoptera: Meliponini) in greenhouses. Neotrop. Entomol. 37 (5), 506-512

Fairbrother, A., Purdy, J., Anderson, T., Fell, R. (2014) Risks of neonicotinoid insecticides to honeybees. Environ. Toxicol. Chem. 33 (4), 719-731

Faria, L.B.D., Aleixo, K.P., Garófalo, C.A., ImperatrizFonseca, V.L., Silva, C.I.D. (2012) Foraging of Scaptotrigona aff. depilis (Hymenoptera, Apidae) in an urbanized area: Seasonality in resource availability and visited plants. Psyche (Camb Mass) . doi:10.1155/ 2012/630628

Feltham, H., Park, K., Goulson, D. (2014) Field realistic doses of pesticide imidacloprid reduce bumblebee pollen foraging efficiency. Ecotoxicology 23 (3), 317-323

Fukuda, H., Sakagami, S.F. (1968) Worker brood survival in honeybees. Res. Popul. Ecol. (Kyoto) 10 (1), 31-39

Gill, R.J., Ramos-Rodriguez, O., Raine, N.E. (2012) Combined pesticide exposure severely affects individual-and colony-level traits in bees. Nature 491 (7422), 105-108

Godfray, H.C.J., Blacquiere, T., Field, L.M., Hails, R.S., Petrokofsky, G., et al. (2014) A restatement of the natural science evidence base concerning neonicotinoid insecticides and insect pollinators. Proc. R. Soc. B 281 (1786), 20140558

Goulson, D. (2013) Review: An overview of the environmental risks posed by neonicotinoid insecticides. J. Appl. Ecol. 50 (4), 977-987

Guedes, R.N.C., Smagghe, G., Stark, J.D., Desneux, N. (2015) Pesticidal stresses in arthropod pests for optimized integrated pest management programs. Annu. Rev. Entomol. 61 (1)

Hartfelder, K., Engels, W. (1989) The composition of larval food in stingless bees: evaluating nutritional balance by chemosystematic methods. Insect. Soc. 36 (1), 1-14

Hartfelder, K., Makert, G.R., Judice, C.C., Pereira, G.A.G., Santana, W.C., Dallacqua, R., Bitondi, M.M.G. (2006) Physiological and genetic mechanisms underlying caste development, reproduction and division of labor in stingless bees. Apidologie 37 (2), 144-163

Haydac, M.H. (1970) Honey bee nutrition. Annu. Rev. Entomol. 15, 143-156

Hendriksma, H.P., Härtel, S., Steffan-Dewenter, I. (2011) Honey bee risk assessment: new approaches for in vitro larvae rearing and data analyses. Methods Ecol. Evol. 2 (5), 509-517

Higginson, A.D., Barnard, C.J. (2004) Accumulating wing damage affects foraging decisions in honeybees (Apis mellifera L.). Ecol. Entomol. 29 (1), 52-59

Klingenberg, C.P. (2011) MorphoJ: an integrated software package for geometric morphometrics. Mol. Ecol. Resour. 11 (2), 353-357
Klingenberg, C.P., McIntyre, G.S., Zaklan, S.D. (1998) Left-right asymmetry of fly wings and the evolution of body axes. Proc. R. Soc. Lond. B Biol. Sci. 265 (1402), 1255-1259

Köhler, H.R., Triebskorn, R. (2013) Wildlife ecotoxicology of pesticides: can we track effects to the population level and beyond? Science 341 (6147), 759-765

Kremen, C., Williams, N.M., Thorp, R.W. (2002) Crop pollination from native bees at risk from agricultural intensification. Proc. Natl. Acad. Sci. U. S. A. 99 (26), 16812-16816

Lima, M.A.P., Pires, C.S.S., Guedes, R.N.C., Nakasu, E.Y.T., Lara, M.S., et al. (2011) Does Cry1Ac Bt-toxin impair development of worker larvae of Africanized honey bee? J. Appl. Entomol. 135 (6), 415-422

Lima, M.A.P., Pires, C.S.S., Guedes, R.N.C., Campos, L.A.O. (2013) Lack of lethal and sublethal effects of CrylAc Bt-toxin on larvae of the stingless bee Trigona spinipes. Apidologie 44 (1), 21-28

Medrzycki, P., Giffard, H., Aupinel, P., Belzunces, L., Chauzat, M.P., et al. (2013) Standard methods for toxicology research in Apis mellifera . J. Apic. Res. 52 (4), 1-60

Menezes, C., Vollet-Neto, A., Fonseca, V.L.I. (2013) An advance in the in vitro rearing of stingless bee queens. Apidologie 44 (5), 491-500

Ministério da Agricultura, Pecuária e Abastecimento (2015) AGROFIT: Sistemas de Agrotóxicos Fitossanitários [online] http://extranet.agricultura.gov.br/agrofit cons/ principal_agrofit_cons (accessed on 02 May 15)

Moraes, S.S., Bautista, A.R., Viana, B.F. (2000) Avaliação da toxicidade aguda (DL50 e CL50) de inseticidas para Scaptotrigona tubida (Smith) (Hymenoptera: Apidae): via de contacto. An. Soc. Entomol. Bras. 29 (1), 31-37

Moure, J.S., Urban, D., Melo, G.A.R. (2013) Catalogue of bees (Hymenoptera, Apoidea) in the Neotropical region [online] http://moure.cria.org.br/ (accessed on 08 December 14)

Nogueira-Neto, P. (1997) Vida e criação de abelhas indígenas sem ferrão. Nogueirapis, São Paulo

Nunes-Silva, P., Hrncir, M., da Silva, C.I., Roldão, Y.S., Imperatriz-Fonseca, V.L. (2013) Stingless bees, Melipona fasciculata, as efficient pollinators of eggplant (Solanum melongena) in greenhouses. Apidologie 44 (5), 537-546

Palmer, A.R., Strobeck, C. (1986) Fluctuating asymmetry: measurement, analysis, patterns. Annu. Rev. Ecol. Syst. 17, 391-421

Pires, V., Arantes, R., Torezani, K.D.S., Rodrigues, W., Sujii, E., et al. (2014) Abelhas em áreas de cultivo de algodoeiro no Brasil. Embrapa, Brasília

Rohlf, F.J. (2008) tpsUtil and tpsDig [cd rom]. State University of New York, New York

Rortais, A., Arnold, G., Halm, M.P., Touffet-Briens, F. (2005) Modes of honeybees exposure to systemic insecticides: estimated amounts of contaminated pollen and nectar consumed by different categories of bees. Apidologie 36 (1), 71-83 
Rosa, A., I'Anson Price, R., Ferreira Caliman, M.J., Pereira Queiroz, E., Blochtein, B., Sílvia Soares Pires, C., Imperatriz-Fonseca, V.L. (2015) The stingless bee species, Scaptotrigona aff. depilis, as a potential indicator of environmental pesticide contamination. Environ. Toxicol. Chem. 34(8), 1851-1853

Roubik, D.W. (1982) Seasonality in colony food storage, brood production and adult survivorship — studies of Melipona in tropical forest (Hymenoptera, Apidae). J. Kansas Entomol. Soc. 55, 789-800

Sakagami, S.F. (1982) Stingless bees. In: Hermann, R. (ed.) Social insects, pp. 361-423. Academic, New York

Suchail, S., Debrauwer, L., Belzunces, L.P. (2004) Metabolism of imidacloprid in Apis mellifera. Pest Manag. Sci. 60 (3), 291-296

Tavares, D.A., Roat, T.C., Carvalho, S.M., Silva-Zacarin, E.C.M., Malaspina, O. (2015) In vitro effects of thiamethoxam on larvae of Africanized honey bee Apis mellifera (Hymenoptera:Apidae). Chemosphere 135, 370-378

Tomé, H.V.V., Martins, G.F., Lima, M.A.P., Campos, L.A.O., Guedes, R.N.C. (2012) Imidacloprid-induced impairment of mushroom bodies and behavior of the native stingless bee Melipona quadrifasciata anthidioides. PLoS One 7 (6), e38406

Tomé, H.V.V., Barbosa, W.F., Corrêa, A.S., Gontijo, L.M., Martins, G.F., Guedes, R.N.C. (2015) Reduced-risk insecticides in Neotropical stingless bee species: impact on survival and activity. Ann. Appl. Biol. . doi:10.1111/aab.12217

Van der Sluijs, J.P., Simon-Delso, N., Goulson, D., Maxim, L., Bonmatin, J.M., Belzunces, L.P. (2013) Neonicotinoids, bee disorders and the sustainability of pollinator services. Curr. Opin. Environ. Sustain. 5(3), 293-305

Villa, S., Vighi, M., Finizio, A., Serini, G.B. (2000) Risk assessment for honeybees from pesticide-exposed pollen. Ecotoxicology 9 (4), 287-297

Wilkins, S., Jarratt, N., Harkin, S., Thompson, H., Coulson, M. (2013) Effects of solvent on the toxicity of dimethoate in a honey bee in vitro larval study. Pest Manag. Sci. 69 (4), 462-463

Wilms, W., Imperatriz-Fonseca, V.L., Engels, W. (1996) Resource partitioning between highly eusocial bees and possible impact of the introduced Africanized honey bee on native stingless bees in the Brazilian Atlantic Forest. Studies Neotrop Fauna Environ. 31 , 137-151

Wu, J.Y., Anelli, C.M., Sheppard, W.S. (2011) Sub-lethal effects of pesticide residues in brood comb on worker honey bee (Apis mellifera) development and longevity. PLoS One 6 (2), e14720

Zerbo, A.C., Silva, M.R.L.M., Brochetto-Braga, M.R. (2001) Protein requirements in larvae and adults of Scaptotrigona postica (Hymenoptera: Apidae, Meliponinae): midgut proteolytic activity and pollen digestion. Comp. Biochem. Physiol. B Biochem. Mol. 129 (1), 139-147 